Volume 8. No. 5, May 2020

International Journal of Emerging Trends in Engineering Research

Available Online at http://www.warse.org/IJETER/static/pdf/file/ijeter89852020.pdf

https://doi.org/10.30534/ijeter/2020/89852020

\title{
Effect of Initial Moisture Content on Unconfined Compressive Strength of Cemented-Fiber-Clay
}

\author{
Amin Chegenizadeh ${ }^{1}$, Hamid Nikraz ${ }^{2}$ \\ ${ }^{1}$ Senior Lecturer, Department of Civil Engineering, Curtin University of Technology, Kent Street, Bentley, Perth, \\ Western Australia 6102, Australia. amin.chegenizadeh@ @urtin.edu.au \\ ${ }^{3}$ Professor, Department of Civil Engineering, Curtin University of Technology, Kent Street, Bentley, Perth, \\ Western Australia 6102, Australia. h.nikraz@curtin.edu.au
}

\begin{abstract}
Compressive strength of soil is an important measure in geotechnical engineering. On the other hand, stabilization of soils has been critical these days due to existence of by-product and recycled materials. This study aims to evaluate effect of initial moisture content (IM) in UCS values. The mixture was prepared as combination of cement and clay and fiber. The percentage of fiber was varied from $5 \%$ to $15 \%$. The IM had significant effect on UCS values.
\end{abstract}

Key Words: UCS, fiber, cement

\section{INTRODUCTION}

Investigation on soil strength both shear and compressive strength being studied in literature [1-10]. As example effective stress investigation in [2], the consideration of non-evasive method [3], anisotropic stresses [4], stress distribution in different applications [5,6]. Some also relevant to stresses in liquefaction [7,10]. The literature for clayey materials raised some concerns especially if the clay is soft and inclined to fail under relatively low stresses. One of the approaches which is popular due to its cost and being quick is unconfined compressive strength (UCS).

On other hand, application of stabilization techniques in its different forms such as fiber, cement, flyash and slag etc being studied as an example, fiber being studied in terms of direct shear, permeability issues, UCS tests, compaction and dynamic behaviour in [11-21], Flyash slag sawdust and waste tyre investigated in among others [22-37]. Fly ash application among others [32-34]. In addition, as an example tyre chips $[36,37]$.

The principle of UCS testing is based on the fact that a compression load is applied till sample fails. This study considers the effect of initial moisture content (IM) into the behavior of soil mixed with cement and fiber. The moisture content is defined as amount of water trapped in soil matrix. The moisture content is calculated as ratio of water mass and dry soil mass. This work is continuation of stabilization research on soil in Curtin university.

\section{MATERIALS}

This study aimed to consider the mixture of clay, fiber and cement. The following sections show the used materials:

\subsection{Clay}

The clay which was used in this study is kaolinite clay. The PSD of kaoline can be seen in Figure 1.

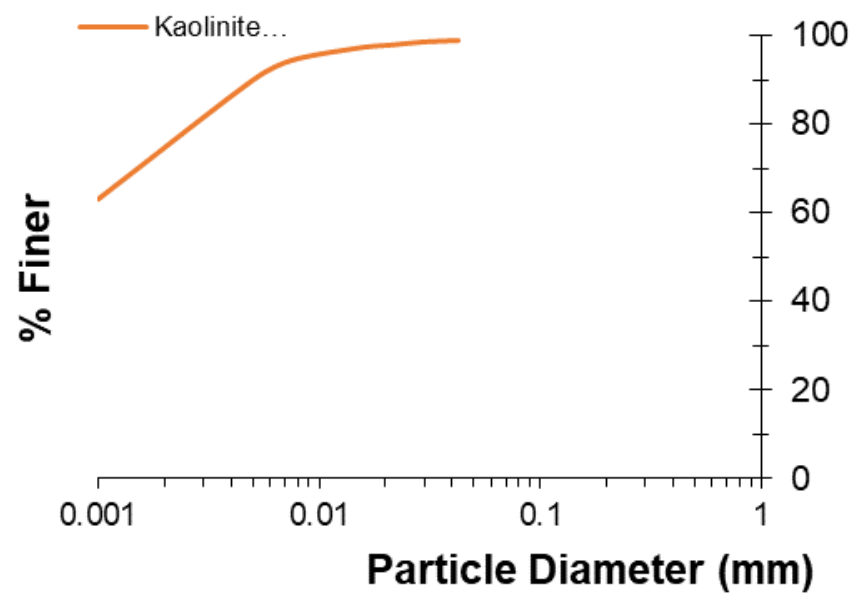

Figure 1: PSD of kaolinte

\subsection{Cement}

Portland cement (PC) was used to build the mixture. The Type II was employed in this study.

\subsection{Fibre}

The fibre used in this study was in gray color and non-rough surface. The length of fiber measured as $10 \mathrm{~mm} \pm 2$.

\subsection{Fillers}

As fillers $0.5 \%$ powdered tyre and $0.5 \%$ flyash was added to the whole mixture. 


\section{TESTING PLAN}

The UCS device was used in this study. The device can be seen in Figure 2. Table 1 presents the characteristics of samples and testing plan.

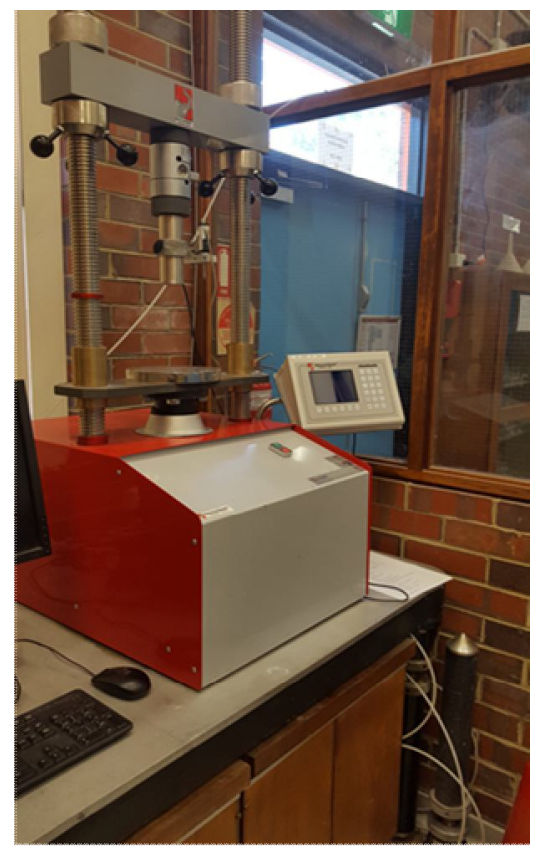

Figure 2: UCS device

Table 1: Testing program utilized in this study

\begin{tabular}{|c|c|c|c|}
\hline Sample ID & PC (\%) & IM/C & $\begin{array}{c}\text { Fiber } \\
(\boldsymbol{\%})\end{array}$ \\
\hline K-5F-5PC & 5 & $0.2,0.4,0.6$ & 5 \\
\hline K-10F-5PC & 5 & $0.2,0.4,0.6$ & 10 \\
\hline K-15F-5PC & 5 & $0.2,0.4,0.6$ & 15 \\
\hline
\end{tabular}

\section{TEST RESULTS}

\subsection{Compaction Results}

Table2 presents the characteristics of compaction. The OMC (optimum moisture content) and MDD (maximum dry density) are presented. Figure 3 and 4 presents a comparison among samples.

Table 2: Results of compaction tests

\begin{tabular}{|c|c|c|c|}
\hline Sample ID & Fiber (\%) & OMC (\%) & MDD \\
\hline K-5F-5PC & 5 & 26 & 1.25 \\
\hline K-10F-5PC & 10 & 27.5 & 1.23 \\
\hline K-15F-5PC & 15 & 29 & 1.22 \\
\hline
\end{tabular}

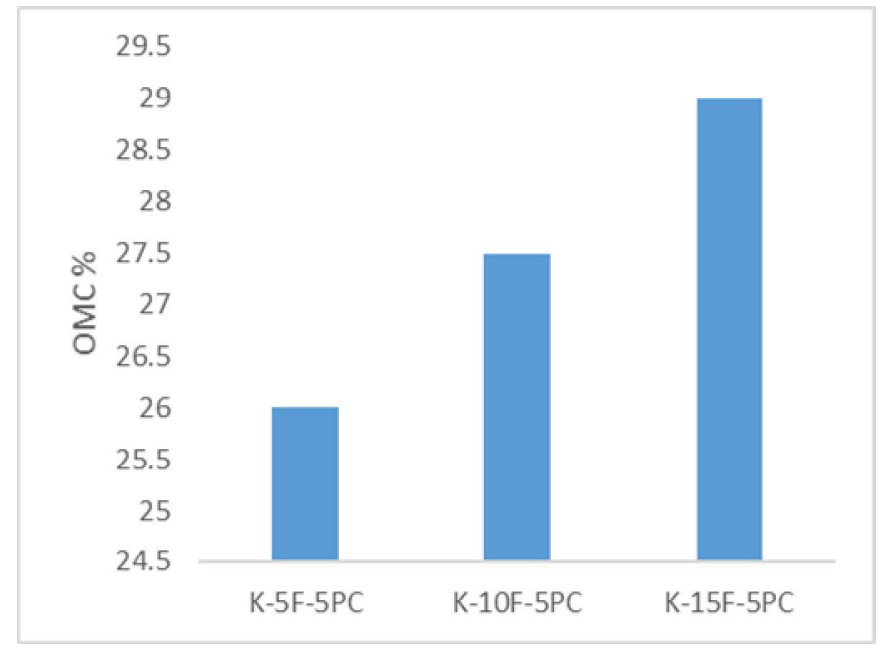

Figure 3: OMC of samples

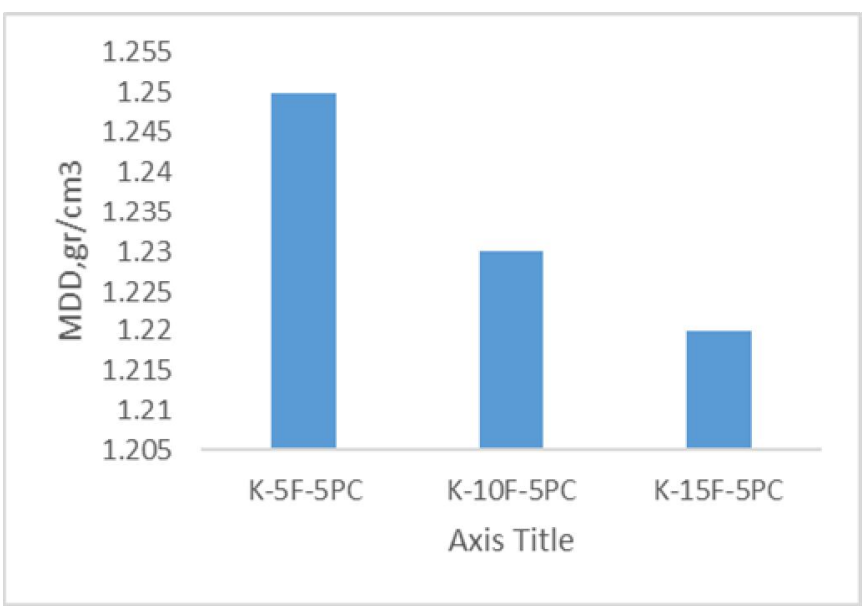

Figure 4 : MDD of samples

\subsection{Unconfined Compressive Strength}

UCS testing were conducted on a soil mixture of fiber dosage of 5,10 and $15 \%$. The cement dosage kept constant at 5percent. The clay mixed with the cement and fiber with percentages explained.

The UCS test was conducted in accordance with Australian standard. The rate of compression was selected as $1 \mathrm{~mm} / \mathrm{min}$. The samples were prepared in different initial moisture contents. The outcome of UCS tests can be seen in Figure 5 to Figure 7. 


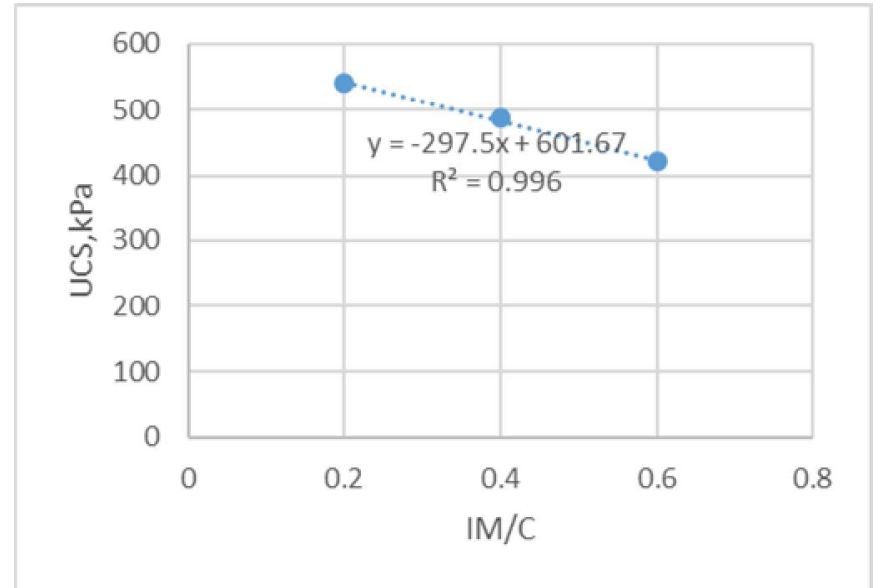

Figure 5: UCS results for 5\% fiber.

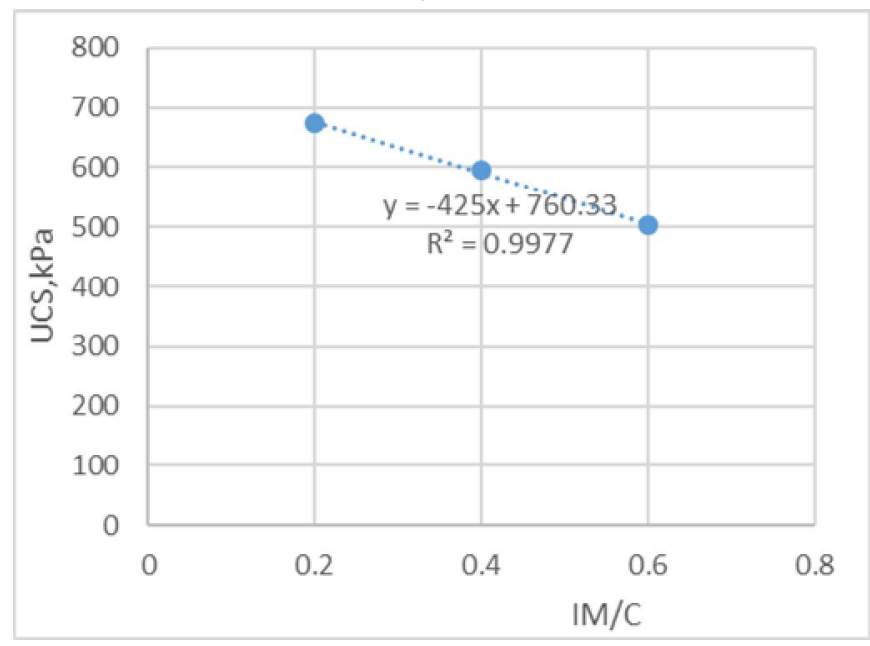

Figure 6: UCS results for $10 \%$ fiber.

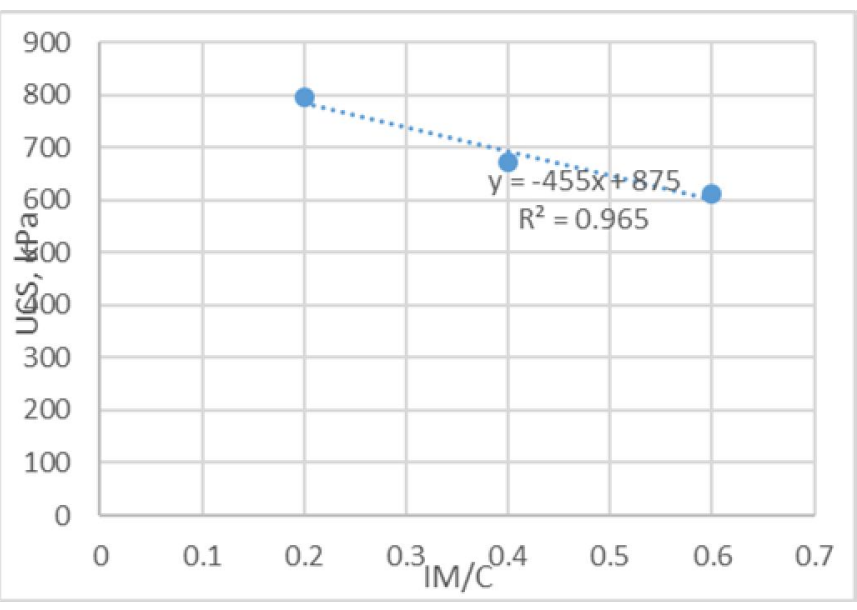

Figure 7: UCS results for $15 \%$ fiber.

\section{CONCLUSION}

A series of compaction tests were conducted, the outcome of compaction shows that with increasing in fiber dosage the OMC increased and MDD decreased. The UCS shows with increasing in IM/C the UCS values dropped in all fiber dosages.

\section{REFERENCES}

[1] Keramatikerman M, Chegenizadeh A. Effect of particle shape on monotonic liquefaction: Natural and crushed sand. Experimental Mechanics. 2017 Oct 1;57(8):1341-8. https://doi.org/10.1007/s11340-017-0313-Z

[2] Owusu-Nimo F, Boadu FK. Evaluating effective stress conditions in soils using non-invasive electrical measurements - Laboratory studies. Journal of Applied Geophysics. 2020;174:103961. https://doi.org/10.1016/j.jappgeo.2020.103961

[3] Al-Rkaby AHJ, Chegenizadeh A, Nikraz H. Anisotropic strength of large scale geogrid-reinforced sand:experimental study Soils and foundations 2017.57 (4), 557-574 https://doi.org/10.1016/j.sandf.2017.03.008

[4] Song Y-S, Hong S. Effect of clay minerals on the suction stress of unsaturated soils. Engineering Geology. 2020;269:105571. https://doi.org/10.1016/j.enggeo.2020.105571

[5] Chegenizadeh A, Ghadimi B, Nikraz H, Simsek M. A novel two-dimensional approach to modelling functionally graded beams resting on a soil medium. Structural Engineering and Mechanics. 2014;51(5):727-41

[6] Higa S, Nagaoka K, Yoshida K. Stress distributions of a grouser wheel on loose soil. Journal of Terramechanics. 2019;85:15-26. https://doi.org/10.1016/j.jterra.2019.07.001

[7] Chiaradonna A, Lirer S, Flora A. A liquefaction potential integral index based on pore pressure build-up. Engineering Geology. 2020;272:105620.

[8] Al-rkaby, A.H.J., Chegenizadeh, A., Nikraz, H.R. Cyclic behavior of reinforced sand under principal stress rotation Journal of Rock Mechanics and Geotechnical Engineering 2017 9(4), pp. 585-598 https://doi.org/10.1016/j.jrmge.2017.03.010

[9] Morimoto T, Aoyagi Y, Koseki J. Effects of induced anisotropy on multiple liquefaction properties of sand with initial static shear. Soils and Foundations. 2019;59(5):1148-59.

[10] Lu C-W, Chu M-C, Ge L, Peng K-S. Estimation of settlement after soil liquefaction for structures built on shallow foundations. Soil Dynamics and Earthquake Engineering. 2020;129:105916. https://doi.org/10.1016/j.soildyn.2019.105916 
Amin Chegenizadeh et al., International Journal of Emerging Trends in Engineering Research, 8(5), May 2020, 2015 - 2018

[11] Chegenizadeh, A., Nikraz, H. Investigation on strength of fiber reinforced clay Advanced Materials Research 2011.261-263, pp. 957-963.

[12] Kurugodu HV, Bordoloi S, Hong Y, Garg A, Garg A, Sreedeep S, et al. Genetic programming for soil-fiber composite assessment. Advances in Engineering Software. 2018;122:50-61.

[13] Chegenizadeh, A. and H. Nikraz, Composite Soil: Fiber Inclusion and Strength, Journal of Advanced Materials Research 2011.1646

[14] Salih MM, Osofero AI, Imbabi MS. Constitutive models for fibre reinforced soil bricks. Construction and Building Materials. 2020;240:117806. https://doi.org/10.1016/j.conbuildmat.2019.117806

[15] Chegenizadeh, A., Nikraz, H. Investigation on compaction characteristics of reinforced soil . Advanced Materials Research 2011 261-263, pp. 964-968

[16] Abdullah NHH, Aziz NHA, Jaafar FF, Osman NM, Ahmad A, Hamid SA. Effect of different fibre reinforcement type to the shear strength of soft soil at varying moisture condition. Journal of Physics: Conference Series. 2019;1349:012126.

[17] Chegenizadeh, A., Nikraz, H. Shear test on reinforced clay Advanced Materials Research 2011, 250-253, pp. 3223-3227

[18] Chegenizadeh A, Nikraz H. Permeability test on reinforced clayey sand. World Academy of Science, Engineering and Technology. 2011;54:130-3.

[19] Selonen S, Dolar A, Jemec Kokalj A, Skalar T, Parramon Dolcet L, Hurley R, et al. Exploring the impacts of plastics in soil - The effects of polyester textile fibers on soil invertebrates. Science of The Total Environment. 2020;700:134451.

https://doi.org/10.1016/j.scitotenv.2019.134451

[20] Gao L, Hu G, Chen J, Ren K, Zhou Q, Yu X. Dynamic properties of carbon-fiber-reinforced clay soil. Soil Mechanics and Foundation Engineering. 2018 Nov 1;55(5):317-24.

https://doi.org/10.1007/s11204-018-9543-Z

[21] Li L, Zhang J, Xiao H, Hu Z, Wang Z. Experimental Investigation of Mechanical Behaviors of Fiber-Reinforced Fly Ash-Soil Mixture. Advances in Materials Science and Engineering. 2019;2019.

[22] Keramatikerman M, Chegenizadeh A, Nikraz H. Experimental study on effect of fly ash on liquefaction resistance of sand Soil Dynamics and Earthquake Engineering,2017. 93, 1-6 https://doi.org/10.1016/j.soildyn.2016.11.012

[23] Arulrajah A, Kua T-A, Horpibulsuk S, Phetchuay C, Suksiripattanapong $\mathrm{C}$, Du Y-J. Strength and microstructure evaluation of recycled glass-fly ash geopolymer as low-carbon masonry units. Construction and Building Materials. 2016;114:400-6.
[24] Sabbar AS, Chegenizadeh A, Nikraz H. Static liquefaction of very loose sand-slag-bentonite mixtures. Soils and Foundations. 2017 Jun 1;57(3):341-56.

[25] Luo YS, Li J, Chan A. Study on the engineering property of mixed-soil fly ash. In Advances in Environmental Geotechnics 2010 (pp. 721-727). Springer, Berlin, Heidelberg.

[26] Keramatikerman, M., Chegenizadeh, A., \& Nikraz, H. An investigation into effect of sawdust treatment on permeability and compressibility of soil-bentonite slurry cut-off wall. Journal of Cleaner Production, 2017.162, 1-6. https://doi.org/10.1016/j.jclepro.2017.05.160

[27]Muntohar AS. Influence of plastic waste fibers on the strength of lime-rice husk ash stabilized clay soil. Civil Engineering Dimension. 2009 Mar 16;11(1):32-40.

[28] Chegenizadeh, A., Keramatikerman, M., Dalla Santa, G., \& Nikraz, H. Influence of recycled tyre amendment on the mechanical behaviour of soil-bentonite cut-off walls. Journal of cleaner production, 2018.177, 507-515

[29] Chegenizadeh A, Keramatikerman M, Panizza S, Nikraz $\mathrm{H}$. Effect of powdered recycled tire on sulfate resistance of cemented clay. Journal of Materials in Civil Engineering. 2017 Oct 1;29(10):04017160.

[30]Yaghoubi E, Arulrajah A, Yaghoubi M, Horpibulsuk S. Shear strength properties and stress-strain behavior of waste foundry sand. Construction and Building Materials. 2020;249:118761.

[31]Arulrajah A, Perera S, Wong YC, Horpibulsuk S, Maghool F. Stiffness and flexural strength evaluation of cement stabilized PET blends with demolition wastes. Construction and Building Materials. 2020;239:117819.

[32]Nath BD, Molla M, Ali K, Sarkar G. Study on strength behavior of organic soil stabilized with fly ash. International scholarly research notices. 2017;2017.

https://doi.org/10.1155/2017/5786541

[33]Brooks RM. Soil stabilization with fly ash and rice husk ash. International Journal of Research and Reviews in Applied Sciences. 2009 Dec;1(3):209-17.

[34]Consoli NC, Prietto PD, Carraro JA, Heineck KS. Behavior of compacted soil-fly ash-carbide lime mixtures. Journal of Geotechnical and Geoenvironmental Engineering. 2001 Sep;127(9):774-82.

[35]Laskar A, Pal SK. Effects of waste plastic fibres on compaction and consolidation behavior of reinforced soil. EJGE. 2013;18:1547-58.

[36] Ghazavi M, Sakhi MA. Influence of optimized tire shreds on shear strength parameters of sand. International Journal of Geomechanics. 2005 Mar;5(1):58-65.

[37]Singh B, Vinot V. Influence of waste tire chips on strength characteristics of soils. Journal of Civil Engineering and Architecture. 2011 Sep 1;5(9). 